\title{
A Case Study in Pedagogical Neglect
}

Teaching Materials on Commercial and Consumer Law (3d ed.). By Richard E. Speidel, Robert S. Summers, and James J. White. St. Paul: West Publishing Co., 1981. Pp. xciii, 1490. $\$ 27.95$.

\section{Douglas Laycock $†$}

Writing a casebook is difficult. It is not enough to know the subject; the author of a casebook must also think about pedagogy. Many casebooks fail dramatically on the second count, and most have problems. Law teachers are forever grumbling about the books available to them. Surprisingly, and unfortunately, the third edition of Speidel, Summers, and White's Teaching Materials on Commercial and Consumer Law is an uncommonly clear case of pedagogical neglect. Speidel, Summers, and White are perhaps the most prominent casebook authors in the field; the hornbook by White and Summers is the standard text. ${ }^{2}$ Moreover, the authors claim to have thought carefully about teaching, about how to interest students, and about how to organize material to facilitate rather than impede understanding. ${ }^{3}$ For all of these reasons, the book seemed a safe choice for my commercial law course when the book I had used became outdated.

Instead, the choice was a disaster. There is no polite way to say what must be said: The book is best used to show how not to write a casebook. There is insufficient information about the law, the organization is awful, many of the problems are unworkable or misleading, and much of the remaining material makes no pedagogical sense.

These shortcomings were especially frustating to me because the book reflects three pedagogical judgments that I endorse wholeheartedly: It emphasizes problems, it explains commercial background, and it attempts to integrate practically related aspects of commercial law that are doctrinally distinct. Properly used, problems are better than cases for teaching students detailed analysis of complex commercial statutes. The most important thing we teach in commercial law is how to work with statutes. Stu-

$\dagger$ Professor of Law, The University of Texas.

1. R. SPEIDEL, R. SUMMERS \& J. WHITE, TEACHING MATERIALS ON COMMERCIAL AND CONSUMER LAW (3d ed. 1981) [hereinafter cited by page number only].

2. J. WHITE \& R. SUMMERS, HANDBOOK OF THE LAW UNDER THE UNIFORM COMMERCIAL CODE (2d ed, 1980).

3. Pp. xxiii-xxiv. 
dents will not memorize all the law, nor will they retain more than a fraction of what they memorize. In any event, memorization would not enable them to do much more than the clerk in the Secretary of State's office. Law faculties must try to teach analytic skills and conceptual structures that will enable students to find and apply the law in novel situations. The relevant skills can be learned only by example and practice. Problems provide the opportunity for that example and practice. Problems are also essential for a less grand reason: There are too many important statutory variations to illustrate by cases alone.

Commercial background is important because most students lack such background, and without it, commerical law is a set of arbitrary rules to be memorized. Integration of doctrinally distinct but practically related material is essential to a coherent picture of the law. It is impossible to teach about security agreements without reference to promissory notes or the trustee in bankruptcy, or to teach about security interests in instruments and documents without reference to the rights of holders.

Thus, my disappointment with the book is not that I prefer a more traditional format. Rather, this critique is on the authors' own terms: They failed to reasonably execute what they attempted. Commercial and Consumer $L a w$ fails because it does not give students enough information about the law, because it is badly organized, and because the problems themselves are badly designed. I will illustrate the casebook's defects by examining the chapters on secured transactions, a part of the book designed to stand on its own in a separate course. ${ }^{4}$

\section{Lack of Information on the Law}

The most common complaint of students in my course was that the book has too little information about the law. This lack of information results from the massive substitution of problems for cases without compensating for the resulting loss of legal exposition.

Cases explain the law. A good case teaches the main points of a Code section and illustrates it by specific application. The facts and the court's analysis help anchor the Code sections in the students' memories. The explanations in cases give students a basis for approaching related problems. That is why casebooks frequently feature principal cases followed by questions and problems. Problems can predominate if they are well organized and designed. But the expository function served by cases must still be served, whether by expanded text or even by partial explanations within the problems. Students cannot be expected to solve problems by consulting the statute alone. We may hope that they can do so by the

\footnotetext{
4. P. xxvi.
} 
end of the semester, but if they could at the beginning, they would not need to take the course.

Commercial and Consumer Law does not have nearly enough exposition of the law. Speidel, Summers, and White largely omit the cases and fail to add the necessary explanations. It is astonishing how few cases there are on such basic article 9 concepts as attachment, perfection, and priority. There are only thirty-three principal cases in the twelve chapters on secured transactions. Of these, twenty-two are in the five chapters covering general intangibles, farm products, default, and bankruptcy. ${ }^{5}$ The seven chapters on the rest of article 9 have only eleven cases, and half of those are of little value. Two are on whether goods become fixtures, ${ }^{8}$ an issue the Code leaves to common law. ${ }^{7}$ One is an article 3 case. $^{8}$ Two cases are pre-Code common law. ${ }^{\circ}$ All of these have their uses, but none serves the expository function of casebook cases: They tell students nothing about the key Code sections. There remain only six other cases on article 9 spread over seven chapters, and three of them can fairly be described as esoteric. ${ }^{10}$

In lieu of cases, the authors occasionally provide textual explanations of statutory sections. ${ }^{11}$ But more often, they simply tell students to read the Code, with nothing more than a list of Code sections and some problems as a guide. Consider three examples.

The first is their treatment of priorities. The authors instruct students to read sections 9-201, 9-301, 9-307, 9-308, 9-309, 9-312, 9-306, 9-313, 9-314, and $9-310 .{ }^{12}$ They then pose five priority problems. ${ }^{13}$ Next there is a four-paragraph note on "The Nature of Priority Rules."14 It offers a few random pieces of information, adds section 9-103 to the list of Code sections students should read, and concludes with the following questions:

5. Pp. 273-435 (chs. 10-14).

6. P. 161 (In re Park Corrugated Box Corp., 249 F. Supp. 56 (D.N.J. 1966); p. 165 (Corning Bank v. Bank of Rector, 265 Ark. 68, 576 S.W.2d 949 (1979)).

7. See U.C.C. $\$ 9-313(1)$ (a) (1977).

8. P. 129 (Factors \& Note Buyers, Inc. v. Green Lane, Inc., 102 N.J. Super. 43, 245 A.2d 223 (1968)).

9. P. 141 (M.M. Landy, Inc. v. Nicholas, 221 F.2d 923 (5th Cir. 1955)); p. 146 (Cooke v. Haddon, 176 Eng. Rep. 103 (Nisi Prius 1862)).

10. P. 107 (In re Leasing Consultants, Inc., 486 F.2d 367 (2d Cir. 1973) (lender who takes security interest in lessor's interest in equipment lease must file on equipment as well as on chattel paper)); p. 189 (Philadelphia Nat'l Bank v. Irving R. Boody Co., 1 U.C.C. Rep. Serv. 560 (1963) (Funk, Arb.) (security interest in goods, perfected before issuance of a nonnegotiable document of title, has priority over security interest in document)); p. 227 (Sherrock v. Commercial Credit Corp., 290 A.2d 648 (Del. 1972) (a prepaying buyer of inventory loses to secured party who repossesses before delivery)).

11. See, e.g., pp. 103-04 (describing $\$ \S 544,547$ of Bankruptcy Code); pp. 126-29 (describing holder in due course rules).

12. P. 89.

13. Pp. 89-90.

14. Pp. 90-91. 
To apply the priority rules intelligently, it is important to understand the rationales behind them. These vary. For a start, see if you can articulate the evident "core" and any "limiting" rationales behind (1) the "first in time" priority of UCC 9-312(5); (2) the "purchase money" exception to UCG 9-312(5) embodied in 9$312(3)$; (3) the rule in 9-301(1)(b); and (4) the two rules in 9-307. Make a list of the different types of considerations that appear to figure in the formuations [sic] of these priority rules. ${ }^{15}$

These are not questions students can answer after reading the preceding paragraphs and the cited Code sections. The final sentence of the note lists three secondary sources that do discuss the nature of the considerations that underlie the priority rules, but there is no discussion of what these sources say. Few students will take seriously the notion that they are supposed to examine all those Code sections, and the secondary sources, in sufficient depth to answer the questions, especially when the casebook devotes only three pages to the topic.

The book's defenders might reply that this is merely an introduction to priorities. It is true that most priority rules, and all major ones, are taken up later in chapters on each kind of collateral. But these separate chapters never consider priority systematically. An instructor who does not want to teach priorities as isolated rules must teach the priority system with no significant help from the casebook.

The second example is the book's treatment of the Tax Lien Act. ${ }^{16}$ The authors paraphrase sections 6321, 6322, and 6323(a) of the Internal Revenue Code, which provide for a federal tax lien with priority that usually dates from the time that the government files notice of the lien. ${ }^{17}$ They do not explain, or even cite, subsections 6323(c) and (d); the entire treatment of these subsections is "a series of simple problems."18 Now as anyone who has ever tried to teach these subsections knows, 6323(c) and (d) are two of the most impenetrable statutory provisions in the English-speaking world. No problem involving these sections is "simple" until one understands them; only a tiny fraction of students could solve these problems on their own. The futility of studying such materials before class leads students to abandon all effort at serious preparation. It makes no difference whether students are completely unprepared or have spent hours with materials that teach them nothing. In either case, the classroom dialogue cannot work.

The third example of inadequate explanation of the law is the authors'

15. Id.

16. I.R.C. $\S \S 6321-6323$ (1976).

17. P. 249.

18. Id. 
treatment of the automatic stay in bankruptcy. After a single sentence explaining that the Bankruptcy Code bars "private" collection activities and authorizes the trustee to use collateral, the authors instruct students to "examine" sections $361,362,363,364$, and $365 .{ }^{19}$ The unannotated text of these five sections covers more than nine pages in a typical statutory supplement, ${ }^{20}$ much of which is irrelevant to the treatment of security interests in bankruptcy. The authors make no effort to help students locate the most important subsections. They do offer a case that is typical of disputes now arising under the key subsections. ${ }^{21}$ The case is conceptually helpful, but it is no aid in untangling the statutory text because it was decided forty-three years before the statute was written. Once again, most students give up on reading the statute before class, and the goal of classroom dialogue is frustrated.

It is easy for instructors and authors to overlook the informational emptiness of this book. For the teacher who already knows the law and is comfortable with the statutes, a citation to a Code section conveys useful information. When the class arrives unprepared, he may think students are lazy or that they were confused by the book's organization. I thought both of these things for a while. But gradually, and by force of repetition, my students set me straight. They could not learn the law from this book, they said, because there was so little law in it. They were right.

\section{Disorganization}

The organization of the secured transactions material is ambitious but unfortunately unworkable. The unit begins with a two-chapter introduction, which includes a lengthy overview of article 9. Then follow seven chapters ostensibly organized around specific types of collateral and around the transactional patterns that typically accompany each type. Finally, there are three chapters on default, including one chapter on the avoiding powers of the trustee in bankruptcy.

The attraction of this structure is that, if successful, it would give students a good sense of how transactions under article 9 really work and how the Code is applied in practice. The inherent disadvantages are of two kinds. One risk is that the legal concepts around which the Code and more traditional casebooks are organized will be unclear to students. By the end of the semester, I had become convinced that this consideration is decisive. Students must have a conceptual framework around which to organize the mass of detail in the Code. The relevant conceptual framework

19. P. 425 .

20. See V. Countryman, A. KaUfman \& Z. Wiseman, Commercial LaW: SElected StatUTES 787-96 (1980).

21. P. 425 (In re Murel Holding Corp., 75 F.2d 941 (2d Cir. 1935)). 
is the structure of the Code, because students must look to the Code to retrieve the law they once studied. The best way to teach them the Code's conceptual structure is to immerse them in it for a semester. A transactional organization, even when carefully executed, tends to conceal that structure by substituting a different organizational principle.

The second risk of transactional organization is that some material will appear more than once and other important material will be omitted. In Commercial and Consumer Law, the overview overlaps with subsequent chapters, and the chapters on different types of collateral overlap each other, because many of the same rules apply to more than one type. I am not convinced that these organizational problems are insuperable. But they require that authors consider very carefully what is to be covered in each section and make those plans clear to both teachers and students. These authors did not do so.

Quite apart from the problems inherent in a transactional approach, the organization of the book within each chapter is incomprehensible. It is impossible to describe in general terms just how badly these materials are put together. Perhaps the best way to make the point is to recite the order in which some material is considered.

Chapter four attempts an overview of secured transactions. This overview is not meant to be a mere introduction. It is intended to teach the "fundamental problems common to the use of most types of personal property as article 9 collateral."22 The book's preface states that it is intended to be "slow going."2s The overview provides the only opportunity for systematic study of the structure of article 9. Its organization is bizarre.

After a half-page introduction ${ }^{24}$ and just over seven pages on the respective roles of the lender's lawyer and the borrower's lawyer, ${ }^{25}$ there is a two-page sketch of security devices existing prior to article $9 .{ }^{28}$ These devices are simply listed without context; there is no hint that the bewildering variety of pre-Code devices resulted from repeated innovative efforts to escape the law of fraudulent conveyances and secret liens. This story, crucial as background to article 9, is scattered over the rest of the book. For example, an "Excursus" on Twyne's Case, ${ }^{27}$ secret liens, and fraudulent conveyances comes some ninety pages later, at the end of a

22. P. 73. For example, with respect to sections 544 and 547 of the Bankruptcy Code, 11 U.S.C. $\S \S 544,547$ (Supp. V 1981), the authors say in their overview, "We will discuss each of them interstitially in later chapters, but now is the time to get a firm grip on them." P. 103.

23. P. xxvi.

24. P. 73.

25. Pp. 73-80

26. Pp. 81-82.

27. 76 Eng. Rep. 809 (Star Chamber 1601). 
chapter on equipment and fixtures, ${ }^{28}$ with no indication that it has anything to do with the variety of pre-Code devices. A note on whether creditors really rely on the debtor's possession of goods is found in the chapter on pledges. ${ }^{29}$ An "Excursus" on a variety of modern situations in which one party has possession of another's assets is contained in the chapter on accounts and inventory. ${ }^{30}$ These issues are inseparable from those of secret liens, but there is no cross reference to the earlier material. Last, in the chapter on farm products, there is a problem based on one of the modern secret lien cases discussed sixty pages before. ${ }^{31}$ For once, there is a crossreference.

The overview's list of pre-Code devices is followed by a confusing and almost unbelievable sequence of short sections. Read this paragraph slowly, or it will make you dizzy. First there is a page and a half on "The Concept and Structure of Article Nine." ${ }^{\text {32 }}$ Next comes a two-page section that treats the definition of security interest, the exclusions in section 9104 , and the conflict-of-laws rules in 9-103.33 The next section, less than a half-page long, introduces section 9-203 on attachment, but asks students to solve a problem on future advances under 9-204. ${ }^{34}$ Next comes a page and a half on perfection, ${ }^{35}$ a half page on default, ${ }^{36}$ and two pages on priorities. ${ }^{37}$ Then the sequence starts over again, with a two-paragraph section on the definition of security interest, ${ }^{38}$ five pages on attachment, ${ }^{30}$ and six pages on perfection and filing. ${ }^{40}$ And this is not all. ${ }^{41}$

The chapters designed to illustrate these principles at work in transactions using particular forms of collateral are not much better. The chapter on the pledge begins with two pages of history, using the pledge of Babylonian slave girls as the primary example. ${ }^{42}$ Then a case discusses which intangibles could be pledged at common law. ${ }^{43}$ The case is followed by

28. Pp. 174-78.

29. Pp. $145-46$.

30. Pp. 254-57.

31. P. 314.

32. Pp. 82-84.

33. Pp. 84-86.

34. P. 86.

35. Pp. 87-88.

36. Pp. 88-89.

37. Pp. 89-91.

38. P. 92.

39. Pp. 92-97.

40. Pp. 97-103.

41. There are sections on the trustee's avoiding powers, pp. 103-06; the risk of misclassifying the collateral, pp. 107-12; the drafting of security agreements, pp. 112-18; the promissory note and negotiability, pp. 118-35; the effect of the security agreement on the note, pp. 135-37; "Other Relevant Documents and Law," p. 137; and "Criteria for Judging a Sound System of Personal Property Security Law," p. 138.

42. Pp. $139-40$.

43. P. 141 (M.M. Landy, Inc. v. Nicholas, 221 F.2d 923 (5th Cir. 1955)). 
questions and problems on two issues: attempts to pledge intangibles, ${ }^{44}$ and pledges of tangibles when the pledgee's possession is ambiguous. ${ }^{45}$ Next is the one-page note on whether creditors actually rely on the debtor's apparent possession of goods. ${ }^{46}$ This issue is not unique to pledges; it is equally relevant to any means of perfection.

The next section, two pages long, consists of an 1862 case of trover for four cases of champagne drunk by a bailee, ${ }^{12}$ followed by questions about damaged collateral under the Code $^{48}$ and a problem on the pledgee's liability for failure to convert convertible securities. ${ }^{48}$ Next, there is a twoparagraph note on repledging pledged securities, ${ }^{30}$ a problem on that issue, ${ }^{\text {si }}$ a problem on a pledgee of a note who negligently releases an endorser's liability, ${ }^{52}$ a page and a half contrasting the new and old article $8,^{53}$ and a page and half on the history of stock certificates. ${ }^{54}$ The teacher's manual that accompanies Commercial and Consumer Law suggests that this whole disparate mess, from slave girls to stock certificates, be taught in one day. ${ }^{\mathrm{s}}$

Consider one more example: the chapter on equipment, fixtures, and other collateral in use. This chapter begins with a two-page introduction. ${ }^{88}$ The authors then reprint a standard security agreement. ${ }^{57}$ Nothing in it is at all unique to equipment or fixtures, and there is no reason it could not have been placed in the overview's section on drafting the security agreement. ${ }^{58}$ Then follow three sets of problems, one set each on attachment, perfection, and priority. ${ }^{58}$ Only one problem hinges on how the collateral is classified, and that problem turns mainly on the definition of consumer goods, which is the subject of a different chapter. ${ }^{60}$ These problems also belong in the overview; they present no issues unique to equipment or fixtures. The next two sections are indistinguishable; both

44. P. 143 (questions); p. 144 (problem 5-1 and part of problem 5-3).

45. P. 144 (problem 5-2 and part of problem 5-3).

46. Pp. 145-46; see supra p. 124.

47. P. 146 (Cooke v. Haddon, 176 Eng. Rep. 103 (Nisi Prius 1862)).

48. P. 147 .

49. P. 148 .

50. Pp. $148-49$.

51. P. 149.

52. P. 150

53. Pp. $150-52$.

54. Pp. 152-53.

55. See R. SPEIDEL, R. SUMmers \& J. White, TEACHING NOTES FOR COMMERCiAl AND CONSUMER LAW TEACHING MATERIALS 25 (3d ed. 1981).

56. Pp, 154-55.

57. Pp. $155-58$.

58. Pp. 112-18.

59. Pp. 158-59.

60. Pp. 158-59 (problem 6-2); pp. 358-93 (chapter discussing security interests in consumer goods). 
explore the definition of fixtures. ${ }^{61}$ Nine pages are devoted to that subject, followed by only three pages on priorities in fixtures. ${ }^{62}$ This material is followed by two pages on future advances ${ }^{63}$ and the five-page "Excursus" on fraudulent conveyances, ${ }^{64}$ neither of which is any more relevant to equipment and fixtures than to other kinds of collateral.

It would be more tedious than helpful to continue this page-by-page review. Three chapters are enough to illustrate the principal problem: The book is cut up into too many small sections, and adjacent sections often have very little to do with each other. Instructors who are already familiar with all the material and who have a firm organizational scheme in hand can cope with the discontinuities. But these discontinuities pose enormous problems for students encountering the material for the first time and trying to form a conceptual structure as they go.

Not only are adjacent sections often unrelated, but closely related or duplicative sections are often far apart. One gets the impression that each chapter was written by one of the three authors, who included whatever interested him without looking at any of his coauthors' work. There are several egregious examples beyond those already noted. In the chapter on accounts and inventory, there is an "Excursus" on the modification of priorities by legal and equitable principles outside the Code. ${ }^{65}$ The "Excursus" consists of four hypothetical cases, none of which involves accounts or inventory. There is no clue as to what non-Code principle is involved; there are only citations to the actual cases that decided each hypothetical. The "Excursus" is unrelated to what comes before and after it. But fifty pages later, in the chapter on general intangibles, there are two cases invoking equitable subrogation to override article 9 priorities. ${ }^{68}$ As usual, there is no cross-reference.

The accounts chapter and the general intangibles chapter both have sections on the rights of secured parties with interests in accounts disputed by the account debtors. ${ }^{67}$ The overlapping sets of problems have no crossreference. The accounts chapter has a case on the rights of buyers who pay cash before delivery; ${ }^{68}$ almost two hundred pages later, the bankruptcy chapter has a problem on the same issue. ${ }^{6 \theta}$ The equipment chapter and the accounts chapter have duplicate problems on the conflict between

61. Pp. 159-68.

62. Pp. 169-71.

63. Pp. 172-74.

64. Pp. 174-78; see supra p. 194.

65. Pp. 237-38.

66. P. 282 (National Shawmut Bank v. New Amsterdam Casualty Co., 411 F.2d 843 (1st Cir.

1969)); p. 287 (Alaska State Bank v. General Ins. Co., 579 P.2d 1362 (Alaska 1978)).

67. Pp. 217-22, 275-78.

68. P. 227 (Sherrock v. Commercial Credit Corp., 290 A.2d 648 (Del. 1972)).

69. Pp. 417-18 (problem 14-5). 
lien creditors and a secured party's future advances. ${ }^{70}$ The second time through, the authors ask students to identify "the reason for the newly added UCC 9-301(4)."11 The reason is to give future advances maximum protection from tax liens. No one could conceivably figure that out unless familiar with the Tax Lien Act, but that act is not mentioned; it comes three sections later. ${ }^{22}$

This duplication and scattering cannot be defended on the grounds that it integrates fact patterns or provides continuing review. That is neither its purpose nor its effect. The lack of cross-references suggests that duplication results from inattention rather than from plan. The effects of this disorganization are nearly all bad. Discontinuities conceal crucial relationships and make it difficult to find specific material relevant to questions and review.

\section{Bad Problems}

The problems are the key to the book. Given the lack of cases or exposition of the law, it is essential that the problems guide students through the Code. There are a few notable exceptions, ${ }^{73}$ but most of the book's problems are blighted by confusing names, unnecessary complexity, and inattention to what is being illustrated. Problems should not test students' ability to keep names straight; they should instead teach points of law and provide practice in reading the Code. There is simply no excuse for making a bank the debtor in a four-party fixture problem, ${ }^{74}$ or for referring to the bank as Daisy and the department store as Marie Louise in a consumer credit problem. ${ }^{75}$ Names of parties should be as easy to remember as possible; these names are deliberately deceptive. Probably a majority of problems have parties with such cumbersome names as Augereau, ${ }^{78}$ Bernadotte, ${ }^{77}$ Brabantio, ${ }^{78}$ Desaix, ${ }^{79}$ Kutuzov, ${ }^{80}$ Lucreta, ${ }^{81}$ and Repeunzel. ${ }^{82}$ This is not deliberately deceptive, but it is a nuisance. Class discussion was regularly distracted by confusion over unfamiliar names that students could neither remember nor pronounce.

\footnotetext{
70. Pp. 173, 237.

71. P. 237.

72. Pp. 248-51.

73. See infra p. 201.

74. P. 170.

75. Pp. 226-27.

76. See p. 173.

77. See p. 171.

78. See id.

79. See p. 100.

80. See p. 159.

81. See p. 144.

82. Sec id.
} 
Many of the problems are far too complex for teaching purposes. Several appear to be old final examination questions, reprinted verbatim. ${ }^{83}$ One even concludes with advice on taking exams: "Be sure to indicate clearly the order of priority and support this conclusion with appropriate citations to and discussion of the relevant Code provisions."

Printing exam questions as teaching problems reflects a profound misunderstanding of the purpose of problems. An exam question should sample material from the whole course; most teaching problems, however, should illustrate single new points. An exam question may conceal issues and challenge students to spot them; a problem should isolate and highlight new material for students. This is not spoon feeding. Digging the answer out of the Code for the first time is challenge enough; students should not have to search for the questions. An exam question can be long and complex. There is a place for complex and difficult problems that challenge students to integrate and apply what they have learned, but only after a series of simpler problems has laid the groundwork. Most problems should be short, and a series of problems should lead students through the material by building up to more complex challenges. Speidel, Summers, and White do not use complex problems that way. They substitute old exams for basic teaching problems. That will never work.

Especially puzzling are the problems that do not illustrate what the authors claim to illustrate. Students can only be confused when the text tells them they are about to work perfection problems and the first three problems have nothing to do with perfection, ${ }^{85}$ when a problem that is supposed to be about foreclosing on chattel paper deals mainly with attachment and perfection, ${ }^{86}$ or when a problem supposedly on preferences in bankruptcy turns out to be about priorities between secured parties and buyers of inventory. ${ }^{87}$

Perhaps the most incredible example of a misleading problem is in the overview. The authors say that problem 4-10 "is designed to introduce sections 544 and 547."88 The problem has eight parts. Three parts turn on sections 541,548, and 551, sections that have neither been introduced nor referred to at this point in the text. The other five parts demand far greater knowledge of sections 544 and 547 than the book has provided. To teach this problem would take at least a week. But such an effort makes no sense, because there is a whole chapter devoted to bankruptcy three hundred pages later. This problem is simply wasted.

83. See, e.g., pp. 247-48, 322-23, 416-18.

84. P. 248.

85. See pp. $259-60$.

86. See pp. $322-23$ (problem 12-4(2)).

87. See pp. 417-18 (problem 14-5).

88. P. 104. 
Other problems are blighted by the authors' failure to ensure that all essential facts are stated and stated correctly. Thus, a problem on multistate transactions says a security interest was perfected, but does not say where. ${ }^{88}$ Another problem has the trustee asserting rights under section $553(\mathrm{a})(3)$, when the pertinent section is $544(\mathrm{a})(3) .^{80}$

Problems like these are inexcusable in any book. But they are especially unforgivable in a book that makes problems the primary teaching tool.

IV. Ignoring the Basics, and Other Miscellaneous Examples of Pedagogical Neglect

The problems are not the only part of the book that is badly designed. Many of the cases and much of the text are also confusing, misleading, or badly chosen. The book suffers from a recurring tendency to emphasize esoteric material without first-or ever-covering the basics.

Consider the overview of promissory notes and negotiability. ${ }^{91}$ In explaining the requisites of negotiability, the authors state that the instrument must have "words of negotiability." such words are. They illustrate the status of a holder in due course, not with a readily understandable case involving failure of consideration, but with a case involving a negotiable note, an oral side agreement that the note is not to be negotiated, and a holder who takes the note after being told of the oral agreement. ${ }^{93}$ The facts of this case are too odd, the parties' behavior too unprofessional, and the legal issue too obscure to illustrate the central principles of the rights of holders in due course. Yet it is the only case on the topic in the overview. The authors offer a note on the shelter principle, although this principle is rarely relevant to secured transactions. ${ }^{94}$ In addition, more than half of this note is not about the shelter principle at all but is a policy analysis of the holder-in-due-course rule. ${ }^{98}$

After this garbled seventeen-page overview of negotiability, the authors proceed as though they had really taught article 3 . The next section offers a difficult set of problems on the interaction of the security agreement and the note. ${ }^{96}$ The first transactional chapter asks students to solve a vastly over-complicated problem in which a promissory note is successively

89. P. 260 (problem 9-2(2)).

90. P. 171 (problem 6-9(1)).

91. Pp. 118-35.

92. P. 123 (citing W. HAWKLAND, COMMERICAL PAPER 19 (1959)).

93. P. 129 (Factors \& Note Buyers, Inc. v. Green Lane, Inc., 102 N.J. Super. 43,245 A.2d 223 (1968)).

94. Pp. 133-35.

95. Pp. 134-35.

96. Pp. 135-37. 
transferred among five different parties and a pledgee releases the liability of an endorser. ${ }^{27}$ The overview of negotiability does not enable students to handle such problems.

Chapter seven covers security interests in goods held by a bailee and the interaction of article 9 with article $7 .^{98}$ The focus of such a chapter should be on the article 9 provisions governing interests in documents and goods subject to documents, with just enough explanation of article 7 to make the underlying transactions comprehensible. A more extensive treatment of article 7 would distract from the focus on article 9 and, in any event, should not precede full treatment of article 3 on negotiable instruments. Once students understand article 3 , they can easily learn about negotiable documents by analogy with negotiable instruments. But this chapter turns out to be the book's primary treatment of article $7,{ }^{, 8}$ eleven hundred pages before the primary treatment of article $3 .{ }^{100}$ The problems run students through the article 7 rules on the duties of a warehouseman and on the rights of holders of stolen documents and documents with forged endorsements. This material is only tangentially related to article 9 security interest law, and it is quite misplaced. The effect is not to integrate article 7 with article 9, but to drop an undigested chunk of one article into the middle of the other.

The most extreme example of ignoring the basics occurs in an overview section entitled "What is the Collateral? - a Pervasive Problem."101 The section consists of In re Leasing Consultants, Inc., ${ }^{102}$ a case holding that a lender who takes a security interest in the lessor's interest in an equipment lease must file on the equipment as well as the chattel paper. It is bizarre to include this case without including any problems on the basic distinctions among inventory, equipment, farm products, and consumer goods; or among chattel paper, instruments, accounts, and general intangibles. If that material were included, Leasing Consultants would make a nice capstone case. With no buildup the instructor cannot teach it "socratically"; he can only explain it.

Other examples of pedagogical neglect are scattered throughout the book. These examples suggest a general inattention to detail. The authors discuss construction financing in terms of assignors and assignees, ${ }^{103}$ despite their own sound admonition to "avoid the use of names which are

97. P. 150 (problem 5-6).

98. Pp. 179-201.

99. There is also a chapter on documentary sales in the sales material. Pp. 898-939.

100. Pp. 1257-1471.

101. Pp. 107-12.

102. P. 107 (486 F.2d 367 (2d Cir. 1973)).

103. Pp. 278-79, 287, 289-91. 
distinguished only by the final two letters." 104 This particular usage is especially indefensible, because the assignor and assignee here turn out to be the debtor and the secured party. There is no reason to conceal this from students by using non-Code terminology. The authors say that there are three types of familiar transactions in which bills of lading are used to secure credit; however, they mention only two, leaving students to wonder about the third. ${ }^{108}$ They also ask what advantages field warehousing has over ordinary inventory financing before they have introduced ordinary inventory financing. ${ }^{108}$

There are also occasional lapses in the updating of materials. There is an unexplained reference to "contract rights," "107 a term abolished in thirty-four states ${ }^{108}$ by enactment of the 1972 Official Text. ${ }^{109}$ The authors ask whether article 9 controls when the United States is the secured party and refer students to a 1971 court of appeals opinion, ${ }^{110}$ without mentioning the recent Supreme Court case that substantially answers that question. ${ }^{11}$ The authors were not unaware of these developments. ${ }^{112}$ Rather, they did not review their manuscript with sufficient care to identify passages requiring amendment.

\section{Are There Any Good Points?}

There are some good things about this book, although not nearly enough to redeem it. The most obvious strength is the book's extensive textual treatment of commercial background. I know one instructor who assigns the book for the explanations of commercial background but assigns his own cases and problems. Some of the cases and problems do serve their intended purposes. A few are notably good, or could be. If the confusing names were eliminated, the problems on fixture priority ${ }^{113}$ would be among the best at leading students through the mysteries of section 9-313. There are nice problems on multiple purchase-money interests in the same collateral, ${ }^{114}$ and on delay by processing officials between filing and indexing, ${ }^{115}$ issues omitted from other casebooks I have used.

104. P. 116.

105. Pp. 199-201.

106. P. 185 (problem 7-1(2)). The chapter on accounts and inventory begins at p. 202.

107. P. 281.

108. 3 U.L.A. 1-2 (Supp. 1983) (U.C.C., table of adopting jurisdictions).

109. U.C.C. \& 9-106 reasons for 1972 changes.

110. P. 307 (citing United States v. Hext, 444 F.2d 804 (5th Gir. 1971)).

111. United States v. Kimbell Foods, Inc., 440 U.S. 715 (1979).

112. See p. 240 (discussing the elimination of "contract rights" as a type of collateral); p. 249 (citing Kimbell Foods).

113. Pp. 170-71.

114. P. 159 (problem 6-3(2)).

115. P. 171 (problem 6-8). 
The authors have a wonderful case illustrating section 544 of the Bankruptcy Code. ${ }^{116}$ The note on debtor's possession of other people's property is very well done. ${ }^{117}$

But these are isolated pearls, scattered through a disorganized informational desert. A few high points cannot make this book teachable. Perhaps the bottom line was provided by my course evaluations: Two-thirds of my students called the casebook "unproductive, often confusing."

Conclusion

An implicit pedagogical theory underlies this review. There is a limit to how much time and effort students will devote to a course, whatever the faculty might prefer. Casebooks and instructors should channel that effort toward developing the most important skills and teaching the most important subject matter. We should bring students to the edge of insight as quickly and painlessly as possible. Then they should be asked to learn by the "socratic" method, but not before. The law has plenty of real difficulties for students to grapple with; it is never necessary to create artificial ones.

If students are forced to scramble for basic information, or if they are distracted by disorganization, misleading notes, and badly designed problems, two bad things happen: Study will be less productive, and students will study even less. We all avoid activities that are frustrating. Throwing unnecessary difficulties in the students' way will not challenge them to work harder; it will discourage them from working at all.

Commercial and Consumer Law plainly fails under this theory. But it also fails on any other. The problem does not seem to be that Speidel, Summers, and White wrote their book on a different pedagogical theory, but rather that they gave little attention to implementing whatever theory they may have had.

116. P. 395 (In re Plonta, 311 F.2d 44 (6th Cir. 1962)).

117. Pp. 254-57. 